\title{
ASSESS THE ROLE OF NURSING EDUCATORS AND HEAD NURSES IN CLINICAL ACCOMPANIMENT FOR TECHNICAL NURSING STUDENTS IN PORT SAID
}

\author{
Heba Moussa Abdel-Samea Hagrass ${ }^{1}$, prof. Samia Mohammed Adam², Gehan \\ Awad Shetawy ${ }^{3}$ \\ B.Sc Nursing Zagazig University ${ }^{1}$, Professor of Nursing Administration Faculty of \\ Nursing Ain Shams University, ${ }^{2}$ Lecturer of Nursing Administration Faculty of \\ Nursing Port Said University ${ }^{3}$
}

\begin{abstract}
Background: As nursing is a practice-based profession, it is essential that pregraduate students are socialized in the clinical learning environment from the start of their training. Consequently, clinical accompaniment is regarded as a vital component of nursing training to offer the necessary support to pre-graduate students. The aim: To determine the role of nurse educators and head nurses in clinical accompaniment for technical nursing students. The research design: Was a correlational descriptive design. The subjects of this study consisted of three groups; all nurse educators with total no. of 30 , all nursing students at fifth year with total no. of 117 at ministry of health technical health institute at Port Said city, health insurance nursing institute at Port Said and ministry of health technical health institute South Sinai government, and all head nurses in El-Mabara hospital, Port said general hospital and Tor Sinai general hospital with total no. of 30, two tools : Were used for data collection as the followings: First tool is questionnaires sheets to collecting data regarding the clinical accompaniment of nursing students in clinical settings from nursing students, nurse educators, and head nurses. The second tool is observational checklists to assess the role of nurse educators and head nurses related to the clinical accompaniment of technical nursing students. The results: Revealed that the highest mean percentage of the studied nursing students $(51.3 \%)$ and nursing educators $(56.7 \%)$ have an acceptable level of perception related to clinical accompaniment in clinical settings, while the highest mean percentage of the studied head nurses $(70 \%)$ have a poor level of perception. Whereas the highest mean percentage of the studied nursing educators $(50 \%)$ and head nurses $(40 \%)$ have a poor role performance during clinical accompaniment of nursing students in clinical settings. The study concluded: That there was a positive correlation between the level of perception and the role performance of nursing educators and head nurses in clinical settings. The study recommended: That there are an obvious needs for conducting training program of clinical accompaniment and evaluates its effectiveness on nursing educators' and head nurses' performance during clinical training of nursing students in clinical settings.
\end{abstract}

Keywords: clinical accompaniment, clinical settings, clinical teaching, head nurses, nursing educators, nursing students. 


\section{INTRODUCTION}

Nursing as a practice-based profession uses clinical learning settings to provide experience with real patients and real problems. In this environment, nursing students are able to use knowledge in practice, develop skills in problem-solving and decision making and develop critical thinking and clinical reasoning skills (Motsilanyane, 2015). In this regard, the most important purpose of nursing education is to provide students with learning opportunities that will enable them to develop critical thinking skills so that they could become competent, independent, critical-thinking nurses. This practice requires independent thinking and a high level of cognitive development. If a student uses problem-solving scientifically, guided by a clinical nurse specialist (Bosch, 2017).

The clinical accompaniment is a process structured by nursing education institutions to facilitate support and direct assistance to student nurses by nurse educators to ensure achievements of the learning outcomes at the clinical facility (Mathebula, 2016). Therefore Clinical accompaniment is a vital component of a nursing program to educate and train competent nurse practitioners (Motsilanyane, 2015).

Mogale (2011) defined accompanier as a registered nurse charged with an obligation to teach skills and knowledge to students who are placed under her supervision for practical experience. On the other hand, a practitioner teaches, guides, shows and demonstrates. On the other hand, Xaba (2015) asserts that with the new clinical teaching changes, it is imperative that even the lecturers who teach theory should also accompany students to bridge the theory-practice gap.

According to Emory (2014) the primary goal for nurse educators is to facilitate students' transfer of the abstract concepts and skills from the classroom to performance in the authentic nursing environment. While Tanicala (2006) clarified that the characteristics of an effective clinical teacher in four areas are: (1) knowledge and clinical competence, (2) teaching skill, (3) relationships with students, and (4) personal characteristics. Creation of an environment in the clinical area that supports student learning requires clinical teachers to possess knowledge of the practice area, clinical competence, knowledge of how to teach and a desire to teach. 
The ward head nurse has the responsibility to supervise the nursing students allocated to his or her wards. They have to ensure that tasks performed by the nursing students are relevant, they must provide details and discuss aspects of the task as well as ensuring whether students do qualify to perform such tasks. And she should also facilitate the personal and professional development of the nursing students and provide the opportunity for evaluation of their learning (Jooste \& Mothiba, 2014).

A technical nursing student is an enrolled nurse undergoing two years diploma program leading to registration as a general technical nurse. The student is also accompanied at a later stage where the student demonstrates and is assessed for competence or lack of competence, then feedback is given by the accompanist for correction (Mogale, 2011). In 2007, 20 secondary schools of nursing (MOH) have been converted to the professional institute. In 2008, professional institutes cover the entire provinces (Cairo, Alexandria, Ismailia, Port Said, Qaliubiya, Kafr ElSheikh, Suez, Giza, Fayoum, Beni Suef, Minya, Sohag, and Luxor). This program is five years in duration; the graduates of these programs hope the opportunity for admission to the nursing college in grade two if they have the average grade point (Aly, 2014).

Therefore, the $\mathrm{MOH}$ current policy approach is to upgrade the quality of nursing education in Egypt which is one of the main problems. Since the shortage of the stock of qualified nurses in Egypt seems to be a function of the restricted supply of university or high institute nursing education, the expansion of improved quality nursing education is a very sensible approach. The focus on upgrading high school nursing education rather than focusing on expanding university education is justified since most nurses in Egypt are high school level nurses. Therefore, the biggest and fastest impact can be created by improving the quality of nursing education of the majority of nurses (Farag, 2012).

\section{Significance of the Study}

There is a lack of proper integration of theory and clinical practice, student accompaniment and clinical supervision (Suyekiye, 2011). The effective clinical accompaniment of student nurses might improve student nurses performance in clinical settings, enhance nursing care standards, improve the quality of patient care and increase the competency of newly qualified nurses (Mogale, 2011). 
The focus of nurse educators and head nurses in the clinical setting include learning of nursing students how to enhance clinical knowledge with actual practice, provide appropriate care for patients and keeping their privacy and dignity. Hence this study was carried out to assess the role of nurse educators and head nurses in clinical accompaniment for technical nursing.

\section{AIM OF STUDY:}

To determine the role of nurse educators and head nurses in clinical accompaniment for technical nursing students. This was achieved through:

1. Assess the level of perception of nursing students, nursing educators, and head nurses about the clinical accompaniment of technical nursing students in clinical settings.

2. Determine the role of nursing educators during the clinical accompaniment of nursing students in clinical settings.

3. Determine the role of head nurses during the clinical accompaniment of nursing students in clinical settings.

4. Find out the relation between perception and the role of nursing educators and head nurses during clinical accompaniment of technical nursing students in clinical settings.

\section{The research questions:}

1. What are the perceptions of student nurses, nursing educators and head nurses regarding the accompaniment of student nurses in the clinical settings?

2. What is the level of role performance of nursing educators and head nurses during clinical accompaniment of nursing students in clinical settings?

3. Is there a relationship between the level of perception of nursing educators and head nurses regarding the clinical accompaniment and level of performance of their role during clinical accompaniment of nursing students in clinical settings?

\section{SUBJECTS AND METHOD:}

Research design: A correlational descriptive design.

Setting: This study was conducted at three technical Health Institutes at the academic year (2016/2017), these are namely (1) Ministry of Health Technical Health Institute at Port-Said governorate, (2) Technical Health Institute at South Sinai governorate and (3) Health insurance nursing institute at Port-Said governorate. 
Also, the present study was conducted at three hospitals namely Al-Mabara hospital at Port-Said governorate, Port-Said general hospital, and Tor Sinai general hospital Subjects: The study was carried out on (117) nursing students at the fifth academic level, (30) nursing educators during the academic year (2016/2017) and (30) head nurses.

The study sample excluded the first four academic levels because they don't have hospital training experience to assess their level of perception regarding the clinical accompaniment of technical nursing students in clinical settings.

Sampling method: No sampling procedures were applied to nursing students, nursing educators or head nurses. The number of each group was relatively small, so the target populations, as a whole, was enabled to participate in this study.

Tools for data collection:-Two tools were used to collect data for this study as follows:

\section{The tool I: Perception questionnaires:}

It was used to assess the level of perception of nursing students, nursing educators, and head nurses about the clinical accompaniment of technical nursing students in clinical settings. This tool was consisting of $\mathbf{5 2}$ items grouped into six parts as follows:

Part (A): include personal and job characteristics of nursing educators include head nurses and nursing students.

Part (B) It consisted of (23) items related to perceptions of nursing students, nursing educators, and head nurses about the actual clinical accompaniment of nursing students in clinical settings.

Part (C) It consisted of (7) items related to the teaching role of nursing students, nursing educators, and head nurses in clinical settings and the role of nursing students in the learning process.

Part (D) It consisted of (10) items related to perceptions of nursing students, nursing educators and head nurses regarding expectations of nursing students in clinical settings.

Part (E) It consisted of (5) items related to the integration of theory and practice during the clinical accompaniment of student nurses.

Part (F) Multiple choice questions related to the perceptions of nursing students, 
nursing educators, and head nurses with regard to aspects of clinical accompaniment in clinical settings consisted of (7) items. The correct answer was scored by one score and the wrong answer was scored by zero.

It was adopted by Sholah (2012) based on Lekhuleni (2002) and additional modification was done and translated by the researcher.

\section{Scoring System:}

The responses of participants were collected range from (5 to 1 ) for each statement. In the first step of the analysis, respondents were answered each item using five Likert scales ranging from strongly disagree (1), disagree (2), nor agree or disagree (3), agree(4), and strongly agree (5). The scores of the items were summed-up for each item and the total divided by the number of the items, giving a mean score for every part. These scores were converted into a percent score, and means and standard deviations were computed. The level of perception was considered to be poor if the percent score was $40 \%$ or less, acceptable if ranged between $41<70 \%$, and good if the percent score was $71 \%$ or more (Altengi \& Ghaith Al-Bahr, 2015).

\section{Tool II: Observational checklists:}

It was aimed to assess the role of nurse educators and head nurses. It was adopted from Abd-Elalim (2007). It consisted of (41) items for nursing educators and (39) items for head nurses grouped into six parts as follows:

Part A: It related to the teaching role during the clinical accompaniment and consisted of (12) items.

Part B: It related to the technical role during the clinical accompaniment and consisted of (4) items.

Part C: It related to the supportive role during the clinical accompaniment and consisted of (6) items.

Part D: It related to acting as a role model during the clinical accompaniment and consisted of (5) items.

Part E: It related to maintaining good communication during the clinical accompaniment and consisted of (7) items.

Part F: It related to maintaining continuous evaluation during the clinical accompaniment and consisted of (7) items.

The observational checklist for head nurses included the same parts except part (F) 
(detecting continuous evaluation during the clinical accompaniment) excluding items related to formative and summative evaluation and consisted of (5) items.

\section{Scoring System:}

In the first step of the analysis, respondents' performance was observed for each item using three Likert scales ranging from poor (1), acceptable (2), and good (3). The second step summed items obtained from the respondents' performance observation of the various parts and the total score was divided by the number of items to calculate the total mean score of every part. These scores were converted into a percent score, and means and standard deviations were computed. The level of performance was considered to be poor if the percent score was $40 \%$ or less, acceptable if ranged between $41<70 \%$, and good if the percent score was $71 \%$ or more (Altengi \& Ghaith Al-Bahr, 2015).

- Tools Validity: Translation of questionnaires sheets into the Arabic language was reviewed by a jury of five experts from the Faculty of Nursing at Port Said University to check their validity and modifications was done according to the results of the jury.

- Reliability of study tools: Cronbach alpha coefficient was calculated to assess the reliability of the tools through their consistency.

- Pilot study: A pilot study was carried out on (3 nurse educator, 3 head nurse, 11 nursing student) who represented $10 \%$ of the total sample. The purpose of the pilot study was to test the applicability and feasibility of the study tools. Also, it served to estimate the time needed to fill in the questions, in addition to finding out any obstacles and problems that might interfere with data collection. The subjects who shared in the pilot study were excluded from the study subjects and completion of tools took 20-30 minutes for each tool.

- Fieldwork: Before distributing the questionnaires, the researcher met the subjects and explained the purpose of the study and the components of the tools, as well as the method of filling them. Subjects of the study were reassured that their information obtained would be confidential while distributing the questionnaire sheet, then an oral agreement was obtained. The data were collected from nursing students, nursing educators in the studied institutes, and from head nurses in the studied hospitals using (tool-1) clinical accompaniment perception questioners. And observed the role of nurse educators and head nurses related to clinical 
accompaniment of nursing students by using (tool-2) in their work settings. This process of data collection was carried out in the period from the end of February 2017 to the end of May 2017. First obtaining an official agreement from the directors of nursing institutes and hospitals was conducted by the researcher on an individual basis to explain the objectives of the study and to gain their cooperation.

\section{Administrative Design:}

Official letters were directed from Dean of Faculty of Nursing in Port Said to directors of Ministry of Health Technical Health Institute at Port Said city, health insurance nursing institute at Port Said and Technical Health Institute at South Sinai government, El-mabara hospital, Port Said general hospital and Tor Sinai general hospital.

\section{Ethical Consideration:}

- The aim of the study was explained to the students, educators, and head nurses included in the study and their permission to participate was taken.

- Students, educators, and head nurses were assured about the confidentiality of the information gathered and that it was used only for the purpose of the study.

\section{Statistical Design:}

In this study, the unprocessed data were coded and entered into a Microsoft Excel (office 2016) spreadsheet, which a statistician analyzed using the Statistical Package for Social Sciences (SPSS) software program version (24). Frequencies and variations for each variable were calculated quantitatively using mean percent. After descriptive analysis, building factors from the questioner and checklist items to represent the total level of perceptions and assess the level of performance by using factor technique (weighted factor method). The results presented in tables and graphs.

\section{RESULTS:-}

Table (1): shows that slightly less than half (47.9\%) of nursing students were from Technical Health Institute at South Sinai governorate, and about more than one third (33.3\%) of them from Health insurance nursing institute at Port Said governorate. While less than one quarter $(18.8 \%)$ of them were from the Technical Health Institute 
at Port Said governorate. Regarding their age, the same table shows that about less than two thirds $(62 \%)$ of them had nineteen years old and about less than one quarter (22\%) of them had eighteen years old, while (15\%) of them had twenty years old. In the same context about more than half $(52.1 \%)$ of nursing students were from the general division, while less than half of them (47.9\%) from the emergency division.

Table (2): shows that less than half $(43.3 \%)$ of nursing educators were from Technical Health Institute at Port Said Governorate, and about less than one third $(30 \%)$ of them from Health insurance nursing institute at Port Said governorate, while slightly more than one quarter $(26.7 \%)$ of them were from the Technical Health Institute at South Sinai Governorate. Regarding their age, more than two thirds $(70 \%)$ of them had from thirty to forty years old, and about less than one quarter $(17 \%)$ of them had from twenty to thirty years old, while $(13 \%)$ of them had forty years old or more. Regarding their scientific department, the highest (23.3\%) of them were medical-surgical nursing while the lowest $(3.3 \%)$ of them were geriatric $\&$ psychiatric nursing. In the same context about less than two thirds $(63 \%)$ of them had a bachelor's degree, while the minority of them (3\%) of them had a technical nursing school 3 years. Regarding their years of experience, about more than half $(53 \%)$ of nursing educators had ten years of experience or less, while less than half $(47 \%)$ of them had more than ten years.

Table (3): shows that the same percentage one third (33.3\%) of head nurses in the three settings (Port Said general hospital, El-Mabara hospital at Port Said, and Tor Sinai general hospital). Regarding their age, the same table shows that about less than two thirds $(63.3 \%)$ of them had from twenty to thirty years old, and more than one third $(36.7 \%)$ of them had thirty years old or more. Regarding their department, the highest (20\%) of them were training team while the lowest $(6.7 \%)$ of them were in-patient \& out-patient departments. Regarding their degree of education, the majority $(80 \%)$ of them had a bachelor's degree, while the minority of them $(3.3 \%)$ had a master degree. Regarding their years of experience, this table shows that about less than two thirds $(63.3 \%)$ of them had less than or equal 10 years, while more than one third $(36.7 \%)$ of them had more than 10 years.

Table (4): shows the total of the level of perceptions of nursing students, nursing educators, head nurses about clinical accompaniment in clinical settings, it was found that about more than half $(51.3 \%)$ of nursing students have acceptable perception about clinical accompaniment in clinical settings, and more than half $(56.7 \%)$ of 
nursing educators have acceptable perception, while more than two thirds (70\%) of head nurses have poor perception.

Table (5): shows the total performance of nursing educators \& head nurses to their role during the clinical accompaniment of nursing students in clinical settings, it was found that half $(50 \%)$ of nursing educators have poor level of performance during the clinical accompaniment of nursing students in clinical settings, while more than one third $(40 \%)$ of head nurses have poor level of performance.

Table (6): shows the relation between the level of perception and level of role performance of nursing educators, it was found that there was a positive correlation (0.446) between the level of perception and level of role performance of nursing educators in clinical settings. And there was a statistically significant relation $(\mathrm{p}=$ $0.014)$.

Table (7): shows the relation between the level of perception and the level role performance of head nurses, it was found that there was a positive correlation (0.478) between the level of perception and level of role performance of head nurses in clinical settings. And there was a statistically significant relation $(p=0.08)$.

Table (1): Demographic characteristics of nursing students according to settings $(\mathrm{N}=117)$

\begin{tabular}{|c|c|c|c|c|c|c|c|c|c|}
\hline \multirow{2}{*}{\multicolumn{2}{|c|}{$\begin{array}{l}\text { Demographic } \\
\text { characteristics }\end{array}$}} & \multicolumn{2}{|c|}{$\begin{array}{c}\text { Technical } \\
\text { Health } \\
\text { Institute at } \\
\text { South Sinai } \\
\text { Governorate }\end{array}$} & \multicolumn{2}{|c|}{$\begin{array}{c}\text { Health insurance } \\
\text { nursing institute } \\
\text { at Port Said } \\
\text { Governorate }\end{array}$} & \multicolumn{2}{|c|}{$\begin{array}{c}\text { Technical Health } \\
\text { Institute at Port } \\
\text { Said } \\
\text { Governorate }\end{array}$} & \multicolumn{2}{|c|}{ Total } \\
\hline & & $\mathbf{N}$ & $\%$ & $\mathbf{N}$ & $\%$ & $\mathbf{N}$ & $\%$ & $\mathbf{N}$ & $\%$ \\
\hline \multicolumn{2}{|c|}{ Sample size } & 56 & $47.9 \%$ & 39 & $33.3 \%$ & 22 & $18.8 \%$ & 117 & $100 \%$ \\
\hline \multirow{3}{*}{ Age/years } & 18- & 14 & $25 \%$ & 8 & $20.5 \%$ & 4 & $18.2 \%$ & 26 & $22 \%$ \\
\hline & 19. & 36 & $64.3 \%$ & 25 & $64.1 \%$ & 12 & $54.5 \%$ & 73 & $62 \%$ \\
\hline & $20+$ & 6 & $10.7 \%$ & 6 & $15.4 \%$ & 6 & $27.3 \%$ & 18 & $15 \%$ \\
\hline \multicolumn{2}{|c|}{ Total } & 56 & $100 \%$ & 39 & $100 \%$ & 22 & $100 \%$ & 117 & $100 \%$ \\
\hline \multirow[b]{2}{*}{ Division } & General & - & - & 39 & $100 \%$ & 22 & $100 \%$ & 61 & $52.1 \%$ \\
\hline & $\begin{array}{c}\text { Emergen } \\
\text { cy }\end{array}$ & 56 & $100 \%$ & - & - & - & - & 56 & $47 \%$ \\
\hline \multicolumn{2}{|c|}{ Total } & 56 & $100 \%$ & 39 & $100 \%$ & 22 & $100 \%$ & 117 & $100 \%$ \\
\hline
\end{tabular}


Table (2): Personal and job characteristics of nursing educators according to settings $(\mathrm{N}=30)$

\begin{tabular}{|c|c|c|c|c|c|c|c|c|c|}
\hline \multirow{3}{*}{\multicolumn{2}{|c|}{ Demographic characteristics }} & \multicolumn{6}{|c|}{ Study settings } & \multirow{2}{*}{\multicolumn{2}{|c|}{ Total }} \\
\hline & & \multicolumn{2}{|c|}{$\begin{array}{c}\text { Technical } \\
\text { Health } \\
\text { Institute at } \\
\text { South Sinai } \\
\text { Governorate }\end{array}$} & \multicolumn{2}{|c|}{$\begin{array}{c}\text { Health insurance } \\
\text { nursing institute } \\
\text { at Port Said } \\
\text { Governorate }\end{array}$} & \multicolumn{2}{|c|}{$\begin{array}{c}\text { Technical } \\
\text { Health } \\
\text { Institute at } \\
\text { Port Said } \\
\text { Governorate }\end{array}$} & & \\
\hline & & $\mathbf{N}$ & $\%$ & $\mathbf{N}$ & $\%$ & $\mathbf{N}$ & $\%$ & $\mathbf{N}$ & $\%$ \\
\hline \multirow{2}{*}{\multicolumn{2}{|c|}{ Sample size }} & 8 & $26.7 \%$ & 9 & $30 \%$ & 13 & $43.3 \%$ & 30 & $100 \%$ \\
\hline & & \multicolumn{8}{|c|}{ Total $=\mathbf{3 0}$} \\
\hline \multirow{4}{*}{ Age/years } & $\leq \mathbf{2 0}$ & 1 & $12.5 \%$ & - & $0 \%$ & 3 & $23.1 \%$ & 4 & $17 \%$ \\
\hline & $\leq \mathbf{3 0}$ & 4 & $50 \%$ & 8 & $88.9 \%$ & 9 & $69.2 \%$ & 21 & $70 \%$ \\
\hline & $\leq 40+$ & 3 & $37.5 \%$ & 1 & $11.1 \%$ & 1 & $7.7 \%$ & 5 & $13 \%$ \\
\hline & Total & 8 & $100 \%$ & 9 & $100 \%$ & 13 & $100 \%$ & 30 & $100 \%$ \\
\hline \multirow{9}{*}{$\begin{array}{c}\text { Scientific } \\
\text { departmen } \\
t\end{array}$} & $\begin{array}{c}\text { Medical and } \\
\text { surgical nursing }\end{array}$ & 2 & $25 \%$ & 2 & $22.2 \%$ & 3 & $23.1 \%$ & 7 & $23.3 \%$ \\
\hline & Administration & 2 & $25 \%$ & 2 & $22.2 \%$ & 1 & $7.6 \%$ & 5 & $16.7 \%$ \\
\hline & Pediatric nursing & 1 & $12.5 \%$ & 1 & $11.1 \%$ & 3 & $23.1 \%$ & 5 & $16.7 \%$ \\
\hline & Obstetric nursing & 1 & $12.5 \%$ & 2 & $22.2 \%$ & 2 & $15.4 \%$ & 5 & $16.7 \%$ \\
\hline & Community health & 1 & $12.5 \%$ & 1 & $11.1 \%$ & 2 & $15.4 \%$ & 4 & $13.3 \%$ \\
\hline & Emergency & 0 & $0 \%$ & 0 & $0 \%$ & 2 & $15.4 \%$ & 2 & $6.7 \%$ \\
\hline & Geriatric health & 1 & $12.5 \%$ & 0 & $0 \%$ & 0 & $0 \%$ & 1 & $3.3 \%$ \\
\hline & Psychiatric Nursing & 0 & $0 \%$ & 1 & $11.1 \%$ & 0 & $0 \%$ & 1 & $3.3 \%$ \\
\hline & Total & 8 & $100 \%$ & 9 & $100 \%$ & 13 & $100 \%$ & 30 & $100 \%$ \\
\hline \multirow{5}{*}{$\begin{array}{l}\text { Education } \\
\qquad \text { al } \\
\text { qualificati } \\
\text { on }\end{array}$} & B.Sc. & 3 & $37.5 \%$ & 4 & $44.4 \%$ & 12 & $92.3 \%$ & 19 & $63 \%$ \\
\hline & M.s & 3 & $37.5 \%$ & 5 & $55.6 \%$ & 0 & $0 \%$ & 8 & $27 \%$ \\
\hline & Doctorate & 2 & $25 \%$ & 0 & $0 \%$ & 0 & $0 \%$ & 2 & $7 \%$ \\
\hline & $\begin{array}{c}\text { Technical nursing } \\
\text { school } 3 \text { years }\end{array}$ & 0 & $0 \%$ & 0 & $0 \%$ & 1 & $7.7 \%$ & 1 & $3 \%$ \\
\hline & Total & 8 & $100 \%$ & 9 & $100 \%$ & 13 & $100 \%$ & 30 & $100 \%$ \\
\hline \multirow{3}{*}{$\begin{array}{c}\text { Years of } \\
\text { experience }\end{array}$} & $\leq 10$ & 2 & $25 \%$ & 4 & $44.4 \%$ & 10 & $76.9 \%$ & 16 & $53 \%$ \\
\hline & $>10$ & 6 & $75 \%$ & 5 & $55.6 \%$ & 3 & $23.1 \%$ & 14 & $47 \%$ \\
\hline & Total & 8 & $100 \%$ & 9 & $100 \%$ & 13 & $100 \%$ & 30 & $100 \%$ \\
\hline
\end{tabular}


Table (3): Personal and job characteristics of head nurses according to settings $(\mathrm{N}=30)$

\begin{tabular}{|c|c|c|c|c|c|c|c|c|c|}
\hline \multirow{3}{*}{\multicolumn{2}{|c|}{ Demographic characteristics }} & \multicolumn{6}{|c|}{ Study settings } & & \\
\hline & & \multicolumn{2}{|c|}{$\begin{array}{c}\text { Port Said } \\
\text { general } \\
\text { hospital }\end{array}$} & \multicolumn{2}{|c|}{$\begin{array}{c}\text { El-Mabara } \\
\text { hospital at port } \\
\text { said }\end{array}$} & \multicolumn{2}{|c|}{$\begin{array}{c}\text { Tor Sinai } \\
\text { general } \\
\text { hospital }\end{array}$} & \multicolumn{2}{|c|}{ Total } \\
\hline & & $\mathbf{N}$ & $\%$ & $\mathbf{N}$ & $\%$ & $\mathbf{N}$ & $\%$ & $\mathbf{N}$ & $\%$ \\
\hline & & 10 & $33.3 \%$ & 10 & $33.3 \%$ & 10 & $33.3 \%$ & 30 & $100 \%$ \\
\hline & & \multicolumn{8}{|c|}{ Total $=30$} \\
\hline \multirow{3}{*}{ Age/years } & $\leq 20$ & 3 & $30 \%$ & 4 & $40 \%$ & 4 & $40 \%$ & 11 & $63.3 \%$ \\
\hline & $\leq 30$ & 7 & $70 \%$ & 6 & $60 \%$ & 6 & $60 \%$ & 19 & $36.7 \%$ \\
\hline & Total & 10 & $100 \%$ & 10 & $100 \%$ & 10 & $100 \%$ & 30 & $100 \%$ \\
\hline \multirow{9}{*}{$\begin{array}{c}\text { Departme } \\
\text { nt }\end{array}$} & Training & 2 & $20 \%$ & 1 & $10 \%$ & 3 & $30 \%$ & 6 & $20 \%$ \\
\hline & Emergency & 2 & $20 \%$ & 2 & $20 \%$ & 1 & $10 \%$ & 5 & $16.7 \%$ \\
\hline & Infection control & 1 & $10 \%$ & 2 & $20 \%$ & 1 & $10 \%$ & 5 & $16.7 \%$ \\
\hline & Kidney dialysis & 1 & $10 \%$ & 2 & $20 \%$ & 1 & $10 \%$ & 4 & $13.3 \%$ \\
\hline & I. C. U & 1 & $10 \%$ & 1 & $10 \%$ & 1 & $10 \%$ & 3 & $10 \%$ \\
\hline & O. R. & 1 & $10 \%$ & 1 & $10 \%$ & 1 & $10 \%$ & 3 & $10 \%$ \\
\hline & In patients & 1 & $10 \%$ & 1 & $10 \%$ & 1 & $10 \%$ & 2 & $6.7 \%$ \\
\hline & Outpatients & 1 & $10 \%$ & 0 & $10 \%$ & 1 & $10 \%$ & 2 & $6.7 \%$ \\
\hline & Total & 10 & $100 \%$ & 10 & $100 \%$ & 10 & $100 \%$ & 30 & $100 \%$ \\
\hline \multirow{4}{*}{$\begin{array}{c}\text { Education } \\
\text { al } \\
\text { qualificati } \\
\text { on }\end{array}$} & B.Sc. & 7 & $70 \%$ & 9 & $90 \%$ & 8 & $80 \%$ & 24 & $80 \%$ \\
\hline & $\begin{array}{c}\text { Technical } \\
\text { nursing school } 3 \\
\text { years }\end{array}$ & 2 & $20 \%$ & 1 & $10 \%$ & 2 & $20 \%$ & 5 & $16.7 \%$ \\
\hline & M.s & 1 & $10 \%$ & 0 & $0 \%$ & 0 & $0 \%$ & 1 & $3.3 \%$ \\
\hline & Total & 10 & $100 \%$ & 10 & $100 \%$ & 10 & $100 \%$ & 30 & $100 \%$ \\
\hline \multirow{3}{*}{$\begin{array}{c}\text { Years of } \\
\text { experience }\end{array}$} & $\leq 10$ & 7 & $70 \%$ & 6 & $60 \%$ & 6 & $60 \%$ & 19 & $63.3 \%$ \\
\hline & $>10$ & 3 & $30 \%$ & 4 & $40 \%$ & 4 & $40 \%$ & 11 & $36.7 \%$ \\
\hline & Total & 10 & $100 \%$ & 10 & $100 \%$ & 10 & $100 \%$ & 30 & $100 \%$ \\
\hline
\end{tabular}


Table (4): the total level of perceptions of nursing students, nursing educators, head nurses about clinical accompaniment in clinical settings

\begin{tabular}{|c|c|c|c|c|c|c|}
\hline \multirow{2}{*}{$\begin{array}{c}\text { The level of } \\
\text { perception }\end{array}$} & \multicolumn{2}{|c|}{ Nursing students } & \multicolumn{2}{c|}{ Nursing educators } & \multicolumn{2}{c|}{ Head nurses } \\
\cline { 2 - 7 } & $\begin{array}{c}\text { Frequenc } \\
\mathbf{y}\end{array}$ & $\begin{array}{c}\text { Percent } \\
\text { \% }\end{array}$ & $\begin{array}{c}\text { Frequenc } \\
\mathbf{y} \\
(\mathbf{N = 3 0})\end{array}$ & $\begin{array}{c}\text { Percen } \\
\mathbf{t}\end{array}$ & $\begin{array}{c}\text { Frequenc } \\
\mathbf{y}\end{array}$ & $\begin{array}{c}\text { Percent } \\
(\mathbf{N}=\mathbf{3 0})\end{array}$ \\
\hline Poor & 39 & $33.3 \%$ & 8 & $26.7 \%$ & $\mathbf{2 1}$ & $\mathbf{7 0 \%}$ \\
\hline Acceptable & $\mathbf{6 0}$ & $\mathbf{5 1 . 3 \%}$ & $\mathbf{1 7}$ & $\mathbf{5 6 . 7 \%}$ & 1 & $3.3 \%$ \\
\hline Good & 18 & $15.4 \%$ & 5 & $16.6 \%$ & 8 & $26.7 \%$ \\
\hline Total & $\mathbf{1 1 7}$ & $\mathbf{1 0 0 \%}$ & $\mathbf{3 0}$ & $\mathbf{1 0 0 \%}$ & $\mathbf{3 0}$ & $\mathbf{1 0 0 \%}$ \\
\hline
\end{tabular}

Table (5): the total performance of nursing educators $\&$ head nurses to their role during the clinical accompaniment of nursing students in clinical settings

\begin{tabular}{|c|c|c|c|c|}
\hline \multirow{2}{*}{$\begin{array}{c}\text { The level of } \\
\text { performance }\end{array}$} & \multicolumn{2}{|c|}{ Nursing educators } & \multicolumn{2}{c|}{ Head nurses } \\
\cline { 2 - 5 } & $\begin{array}{c}\text { Frequency } \\
(\mathbf{N}=\mathbf{3 0})\end{array}$ & $\begin{array}{c}\text { Percent } \\
\%\end{array}$ & $\begin{array}{c}\text { Frequency } \\
(\mathbf{N}=\mathbf{3 0})\end{array}$ & $\begin{array}{c}\text { Percent } \\
\%\end{array}$ \\
\hline Poor & $\mathbf{1 5}$ & $\mathbf{5 0 \%}$ & $\mathbf{1 2}$ & $\mathbf{4 0 \%}$ \\
\hline Acceptable & 8 & $26.7 \%$ & 11 & $36.7 \%$ \\
\hline Good & 7 & $23.3 \%$ & 7 & $23.3 \%$ \\
\hline Total & $\mathbf{3 0}$ & $\mathbf{1 0 0 \%}$ & $\mathbf{3 0}$ & $\mathbf{1 0 0 \%}$ \\
\hline
\end{tabular}

Table (6): Relation between the level of perception and the level of role performance of nursing educators

\begin{tabular}{|c|c|c|c|}
\hline & & $\begin{array}{c}\text { Nursing } \\
\text { educators' } \\
\text { perception }\end{array}$ & $\begin{array}{c}\text { Nursing } \\
\text { educators' } \\
\text { performance }\end{array}$ \\
\hline \multirow{2}{*}{$\begin{array}{c}\text { Nursing } \\
\text { educators' level of } \\
\text { perception }\end{array}$} & $\begin{array}{l}\text { Pearson } \\
\text { Correlation }\end{array}$ & 1 & 0.446 \\
\hline & Sig. & & 0.014 \\
\hline \multirow{2}{*}{$\begin{array}{c}\text { Nursing } \\
\text { educators' role } \\
\text { performance }\end{array}$} & $\begin{array}{l}\text { Pearson } \\
\text { Correlation }\end{array}$ & 0.446 & 1 \\
\hline & Sig. & 0.014 & \\
\hline
\end{tabular}


Table (7): Relation between the level of perception and the level role performance of head nurses

\begin{tabular}{|c|l|c|c|}
\hline \multicolumn{2}{|c|}{} & $\begin{array}{c}\text { Head nurses' } \\
\text { perception }\end{array}$ & $\begin{array}{c}\text { Head nurses' } \\
\text { performance }\end{array}$ \\
\hline $\begin{array}{c}\text { Head nurses' level of } \\
\text { perception }\end{array}$ & Pearson Correlation & 1 & 0.478 \\
\cline { 2 - 4 } $\begin{array}{c}\text { Head nurses' role } \\
\text { performance }\end{array}$ & Sig. & & $\mathbf{0 . 0 0 8}$ \\
\cline { 2 - 4 } & Pearson Correlation & 0.478 & 1 \\
\hline
\end{tabular}

\section{DISCUSSION:}

Clinical nursing training forms an integral part of professional nursing education as it equips the student with the necessary knowledge, attitudes, skills, and values required for optimal practice in real situation Anarado et al. (2016). Clinical accompaniment takes place in conjunction with direct involvement and physical presence of a tutor, supplemented by the availability of guidelines and learning aids (Bosch, 2017).

The primary role of nurse educators is to facilitate students' transfer of the abstract concepts and skills from the classroom to performance in the authentic nursing environment (Emory, 2014). On the other hand Letswalo \& Peu (2015) reported that the provision of appropriate clinical accompaniment of student nurses in the clinical environment is acknowledged to be problematic due to the variety of reasons; which included inadequate staffing levels, shortage of equipment, heavy workloads and insufficient time to execute nursing duties due to high nurse-patient ratio.

So that the present study aimed to determine the role of nurse educators and head nurses in clinical accompaniment for technical nursing students.

Results of the present study revealed that the highest percentages of the studied nursing students (62\%) were between 19 and 20 years of age, they were at late adolescent and early adulthood stage in this developmental stage nursing students might experience transitional psycho-social problems, this problems might affect their performance in clinical settings, so that they need adequate support from both 
nursing educators and head nurses during clinical accompaniment in clinical settings to enhance students self-concept and confidence. In congruence with this Behr et al. (2013) who cited that at cognitive, psychomotor and affective skills development might be affected by the psycho-social problems related to this transitional period. Lekhuleni (2002) reported that nursing students might perform poorly in the classroom and clinical settings due to the lack of support and trust from nurse educators and unit supervisors. It is expected that nursing educators and head nurses should provide special support to nursing students during this transitional developmental period.

The current study included the senior year nursing students in the studied settings (at the fifth academic year), the final year nursing students were more experienced in clinical training and this supported the current study. This is in line with the study conducted by Mampunge (2013) who describe the preparedness of final year nursing students for becoming registered nurses. It emerged from the study that some of the final year nursing students experienced a lack of preparedness and others felt adequately prepared to take on the role of a professional nurse. Lack of preparedness was attributed to factors that included curriculum-related aspects, clinical teaching and learning support, learning opportunities, interpersonal relationships between (lecturers, students, and clinical staff) and equipment and library resources during the course of training.

Regarding sociodemographic data for nursing educators and head nurses, the findings of the present study indicated that the years of experience of nursing educators ranged from one to 21 years, while the years of experience of head nurses ranged from 6 to 18 years. This is agreement with that is reported by Rohatinsky (2008) who reported that older more experienced nurses played a greater psychosocial function in the mentorship than did younger ones. Also, nurse teachers with prior mentoring experience were more willing to mentor. Also this in agreement with Aly (2014) who stated that experience years add to the competence of those working in teaching, especially in practical teaching as in the discipline of nursing.

As regarding total level of perception of nursing students and nursing educators about clinical accompaniment, the results of the current study revealed that about more than half of both nursing students $(51.3 \%)$ and nursing educators $(56.7 \%)$ had 
acceptable level of perception, this means that what the students learn in the classroom are not made actually in real life situations in the clinical settings this results might be due to the number of nurse educators is inadequate, the few available ones are faced with the problems of coping with a large class of students for the classroom work and clinical supervision in clinical settings.

This results supported the findings in the study done by Uchechukwu (2014) who showed that that majority of nursing students was reported that their teachers acted mainly as practical examination evaluators but not as clinical facilitators/supervisors. Also, the students were confused because of what they learned in the classroom were different from what was done in the clinical areas, leading to a lack of integration of theory into clinical practice.

Furthermore, the findings of the present study indicated that more than two thirds (70\%) of head nurses have a poor level of perception about clinical accompaniment in clinical settings, this findings might be due to shortages of staff and materials (e.g., equipment) to carry out all the requirements for nursing responsibilities including accompanying nursing students during their clinical training, Time management was an important problem cited by both nursing educators and head nurses. The problem is certainly related to the increasing numbers of students, which outnumber the available stuff, facilities and time allocated.

This finding is similar to that of a study conducted by Magerman (2015) who reported that the participants often over-compensated for the extra workload demands by working faster and working without breaks. The author also states that head nurses, whose time with their student is limited, have reduced opportunities to assess their practice due to the workload assigned to clinical supervisors, they had limited periods of time to spend with each student in the clinical setting. The participants also mentioned that the lack of time prevented them from planning their work, and reported that they felt physically 'burnt out' and tired, as a result of rushing to different clinical settings to supervise students and hurriedly complete the procedures with them.

On the contrary, with the study conducted by Lekhuleni (2002) there was congruence in the perceptions of the three groups of respondents, namely, nursing students, 
nursing educators, and head nurses. They had positive perceptions with regard to accompaniment in clinical settings. These positive perceptions might enable nurse educators and unit supervisors to improve the accompaniment of student nurses in clinical settings.

Regarding the total performance of nursing educators to their role during clinical accompaniment in clinical settings, the current study revealed that half $(50 \%)$ of the studied nursing educators had a poor level of performance, this findings might be due to nursing educators are not always available in clinical settings due to increase the workload between functional responsibilities of theoretical education in classroom and practical training in clinical settings, another reason is inadequate staff and facilities.

These findings agreed with Lekhuleni (2002) who clarified that nursing educators are not always available in clinical settings due to the need to comply with academic responsibilities such as teaching, administration, and research, while the availability of nurse educators in clinical settings contributed to the improvement of accompaniment. The availability of nurse educators in clinical settings was essential for the correlation of theory taught in the classroom and the practical situation in the clinical setting. Also, the study done by Uchechukwu (2014) revealed that one of the constraining factors to appropriate acquisitions of nursing skills because the teachers may not finish the course work on time and the students may not be adequately supervised during clinical experiences.

Also, the present study findings revealed that the highest percentage (40\%) of head nurses had a poor level of performance during clinical accompaniment in clinical settings, this results might be due to incompetent head nurses, lack of experience, insufficient staff in clinical settings and increased workload.

This finding is in line with the study done by Uchechukwu (2014) who reported that there were a few ward staff nurses occasionally do supervise the students. This may be due to the shortage of these nurses or overloaded work, and that the ward staff nurses were not concerned about what students learn. Staff nurses were busy with their duties therefore not able to assume both educational and service role while on duty. Lack of proper supervision will lead to wrong learning of nursing skills, 
laziness, and non-motivation on the part of the students. Also, Bray et al. (2011) indicated that the school skill laboratory and the hospital wards lacked equipment and other necessary supplies, which do not help students to practice and concretize what they learned in the classroom.

As regard to the correlation between the level of perception and the level of role performance of nursing educators and head nurses during clinical accompaniment of technical nursing students in clinical settings, the result of the present study showed that there was a positive correlation (0.446) between level of perception and level of role performance of nursing educators and also indicated that there was a positive correlation (0.478) between the level of perception and level of role performance of head nurses in clinical settings, so nursing educators and head nurses should have more knowledge to enhance their perception regarding clinical accompaniment, which could improve their performance.

Finally, there was a statistically significant relationship between the level of perception and the level of role performance of nursing educators $(p=0.014)$ and head nurses $(\mathrm{p}=0.08)$ during clinical accompaniment of technical nursing students in clinical settings.

\section{CONCLUSION:}

Based on the findings of the present study, it can be concluded that: Based on the finding of the present study, it was concluded that the majority of the studied nursing students and nursing educators have an acceptable level of perception related to clinical accompaniment in clinical settings. While the majority of the studied head nurses have a poor level of perception about clinical accompaniment of nursing students in clinical settings .

Meanwhile, the highest percentage of studied nursing educators and head nurses have poor performance during clinical accompaniment of nursing students in clinical settings. Whereas, there were a positive correlation and statistically significant relation between the level of perception and the role performance of nursing educators and head nurses in clinical settings. 


\section{RECOMMENDATIONS:}

\section{The main recommendations include the following:}

- Increase collaboration between nursing academic and nursing practice in the selection of learning opportunities and the formulation of clinical learning outcomes.

- Frequent meetings and clinical updates between all nursing educators and head nurses involved in student teaching.

- Nursing students should be guided about their role during accompaniment in clinical settings.

- The employment of preceptors by nursing education institutions to complement the nurse educators in clinical settings due to their clinical expertise and due to being unit-based.

- Employing mentors to be based at all clinical facilities for continuous student support.

- All involved in the training and supervision of students should be updated with current trends in nursing and research through seminars and conferences so that they can impart such knowledge to students.

- Learning objectives should be communicated to nursing students, head nurses, nursing educators in order to prepare them for their teaching and learning expectations.

- Formulation of an accompaniment tool according to suggested guidelines and guided by the nursing process.

- Ensure that nursing educators draw up individual clinical accompaniment programs which are accessible to nursing students and head nurses to oversee their implementation.

- Clinical placements need to be well coordinated, taking into consideration the correlation of theory to practice and length of placements that ensures attainment of student's learning objectives.

\section{For further studies:}

> Further research is necessary to design and implementation of clinical accompaniment program and evaluates its effectiveness on nursing educators' and head nurses' performance during clinical training of nursing students in clinical settings.

An accompaniment tool must be developed according to suggested guidelines which 
will be easily used by both lecturers and clinical facilitators in all training programs.

\section{REFERENCES:}

Abd-Elalim E. (2007): Designing and implementing a clinical teaching program for preparing hospital preceptors in Cairo university hospital. Unpublished doctorate thesis. Faculty of nursing. Cairo University.

Altengi M. \& Ghaith Al-Bahr (2015): Analytics of questionnaires using IBM SPSS. Publisher: SABR Center for Statistical Studies and Public Policies, 89.

Aly M. S. (2014): Perception of Teachers and Students Regarding Educational Program in Technical Institutes of Nursing. Journal of Education and Practice, 5(6), 86-101.

Anarado A. N., Agu G. U. \& Nwonu E. I. (2016): Factors hindering clinical training of students in selected nursing educational institutions in Southeastern Nigeria. Journal of Nursing Education Today, 40 (2016):140-145.

Baraz S., Memarian R. \& Vanaki Z. (2015): Learning challenges of nursing students in clinical environments: A qualitative study in Iran, journal of education and health promotion, $4(52): 2$.

Behr A.L ‘.Cherian V.i. \& Mwamwenda T.S. (2013): An Educational Psychology for Schools in Africa, 23.

Bosch H. D. (2017): Facilitation of the student nurse by a clinical nurse: the learner experience. Published Master thesis. Faculty of nursing. University of South Africa.

Bray, L. Flynn, A. \& Sanders, C. (2011): The experiences of children's nursing students: learning urethral catheterization. Nurse Education in Practice, 11(3) 168-172.

Emory J. (2014): Understanding backward design to strengthen curricular models. Nurse Educator, 39(3):122-125. 
Farag M. (2012): Economic Analysis of the Nurse Shortage in Egypt. School of Public Health, Belfer Center for Intl Affairs, Harvard University.

Gaberson K. B. \& Oermann M. H. (2015): Clinical teaching strategies in Nursing. ( $5^{\text {th }}$ Ed.). New York: Springer Publishing Company.

Jooste K. \& Mothiba T. M. (2014): A conceptual framework for cost management training in the Limpopo Province of South Africa. Journal of Nursing Management, 22 (7): 872-883.

Lekhuleni M. E. (2002): The perceptions/views of nursing students, nurse educators and unit supervisors on accompaniment of nursing students in the clinical setting, 160-191.

Letswalo L. O. \& Peu M. D. (2015): Perceptions of student nurses regarding accompaniment in the clinical environment in Gauteng Province, South Africa. African Journal for Physical, Health Education, 1(2): 351-368.

Magerman J. (2015): Clinical supervisors experience of supervising nursing students from a higher education institution in the Western Cap. Faculty of Community and Health Science, University of the Western Cape.

Mampunge F. (2013): Experiences of final year nursing students at a public college of nursing in the Eastern Cape Province regarding their preparedness to become registered nurses. The School of Health Sciences at the University of Fort Hare.

Mathebula T. C. (2016): Challenges facing student nurses in the clinical learning environment in Limpopo province. Health studies, University of South Africa

Mogale L. (2011): Students nurses' experiences of their clinical accompaniment. University of South Africa. 
Motsilanyane P. T. (2015): Exploring the clinical accompaniment challenges second-year students experience at a nursing education institution in North West, 19.

Rohatinsky N. K. (2008): Mentoring Perceptions of Registered Nurses A Thesis Submitted to the College of Graduate Studies and Research in Partial Fulfillment of the Requirements for the Degree of Master of Nursing in the College of Nursing University of Saskatchewan, Saskatoon, Saskatchewan.

Sholah E. A. M. (2012): Efficiency of accompaniment of nurse educators and unit supervisors to nursing students in clinical setting, Tanta University.

Suyekiye M. N. (2011): Factors that affect theory-practice integration of student nurses at a selected campus of a nursing college in the Limpopo province, South Africa. Journal of Nurse Education Today, 35 (1): 170-175.

Tanicala (2006): Design and implementation of nursing students' clinical experiences and program effectiveness as measured by nclex-rn pass rates. Bowling Green State University, School of Leadership and Policy Studies.

Uchechukwu A. G. (2014): Factors affecting clinical training of students in selected nursing educational institutions in Enugu and Ebonyi states of Nigeria. Faculty of Health Science and Technology, University of Nigeria.

Xaba N. P. (2015): The assessment of the facilitation of the clinical training component of an undergraduate nursing program at a University of Technology. 


\section{تقييم دور معلمات التمريض ومشرفى الأقسام فى المرافقة الإكلينيكية لطلبة المعاهد الفنية}

\section{للتمريض}

هبه موسى عبد السميع هجرس، سامية محمد عبدالله ادم، جيهان عوض شتيوى

أخصائية تمريض، أستاذ إدارة التمريض - كلية التمريض - جامعة عين شمس ، مدرس إدارة التمريض ـ كلية التمريض -جامعة بورسعيد

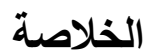

التمريض هو مهنة أساسها الممارسة العملية ولهذا فمن الضرورى أن يختلط طلاب التمريض بالبيئة الإكلينيكية

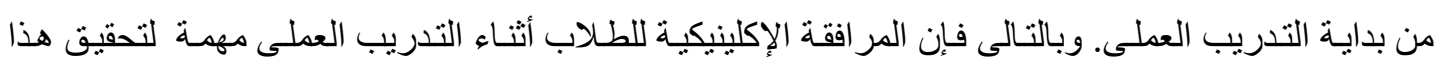
الهدف كما يعزز التكامل بين التعليم النظرى و التطبيق العملى ـ و المتوقع هو أن معلمـات التمريض ومثرفى لإنى



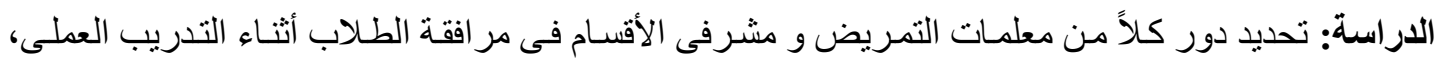
مكان البحث ثلاثة معاهد و هى المعهد الفنى الصحى ببورسعيد و المعهد الفنى للتمريض بالتأمين الصحى و المعهد الفنى للتمريض بجنوب سيناء ـ وثلاثة مستشفيات وهى مستشفى المبرة للتأمين الصحى ومستشفى بورسعيد العام ومستشفى طور سيناء العام. و إثتـملت عينة البحث على كل طلاب الفرقة الخامسـة بالمعاهد المذكورة و عددهم 117 ـ وكل معلمات التمريض بها و عددهم 30 وجميع مشرفى الأقسام بالمستشفيات المذكورة التى يتم التدريب العملى بها وعددهم 30. و الأدوات المستخدمة أداتين بحث الأداة الأولى تتكون من ثنلاث إستبيانات لتقييم درجة و عى طلاب التمريض و معلمـات التمريض و مشرفي الأقسام بالمر افقة الإكلينيكيـة من معلمـات

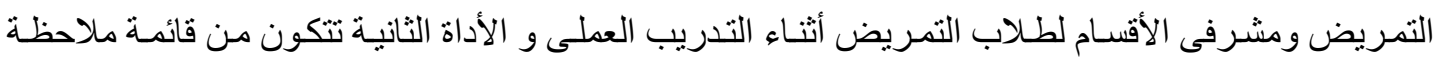

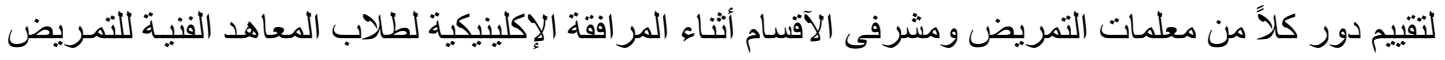
أثناء التدريب العملى. النتيجة: أوضحت نتيجت هذه الدر اسـة وجود علاقة إرتباط معنويـة بين وعى معلمـات التمريض و مشرفى الأقسام بالمر افقه الإكلينيكية و بين أدائهم الفعلى فى مر افقة الطلاب أثناء التدريب العملى و ولهد

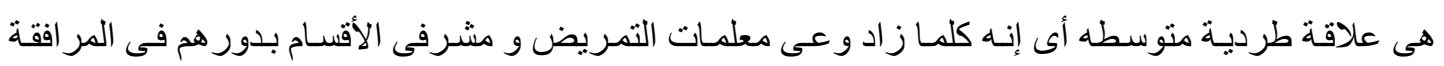

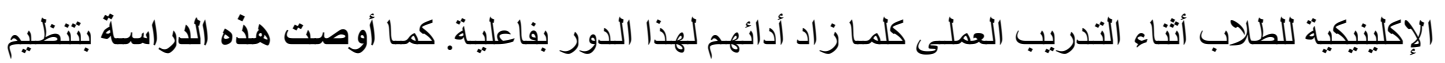
بر امج تدريب لمعلمات التمريض بالمعاهد التمريض ومشرفى الاقسام بالمستشفيات عن المر افقة الإكلينيكية مـع

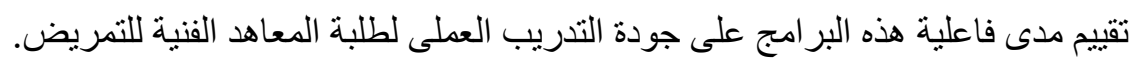

الكلمات المرشدة : التعليم الإكلينيكى، المر افقة الإكلينيكية، معلمات التمريض، مشرفات الأقسام، طلاب

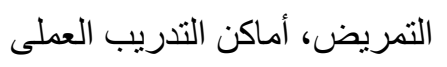

